\title{
A Study on Customer Preference towards Electronic Goods
}

\author{
Dr.S. Aravinth
}

\begin{abstract}
The preference of customers is nothing but the required a product or commodity according to their expected features and attributes. In this regard the researcher is dealt with the housewife and taken them as respondents in the name of customer on their choices of purchasing electronic goods. In this fast moving world, the city life has much more advanced in many schedules. Without the adoption of electronic good one family could not be a competed one in the society. The family is always lead by the women, who shares the half of the burden of the leader for a family. In such a situation she preference more advanced and supporting commodities which fulfils her day to day works. The researcher has designed a framework or a task which is actually leads to find the significant relationship between the wife acceptance factor and the electronic goods [1]. This will also gives an opportunity to the retailers who actually deals with the electronic consumer goods, to know the exact behaviour of the family administrator on purchasing electronic commodities.
\end{abstract}

\section{INTRODUCTION}

$\mathrm{T}$ HERE are premier consumer goods manufacturers exist in this era. This is, of course called buyers' market where numerous products had their shapes, design, and size to satisfy its consumer. In this manner only they become customized [3]. According to many research results the home maker became a prevailing role in purchasing electronic goods. The reason is they are the persons who used these electronic products in home frequently. Marketers are streamlining the demanddriven operations, optimize costs and create more powerful brands with the deep domain knowledge and prove tools and techniques.

Trends and innovation is widely recognized on the focus of home makers for their best preferences. Authority on global trends, rapid business model change, business transformation during economic uncertainty and the necessity for fast-paced innovation are all the internal business strategies has move the business already to a height. In further, the significant consumer electronic goods would transform the common purchasing idea towards a focused one for the convenience of these consumers. It leads a continue transition of the revenue source of the retailers as well as the manufacturers. So, what makes or what can the manufacturers crafting style will bring

Dr.S. Aravinth, Associate Professor, School of Management, Sri Krishna College of Technology, Coimbatore, India. the most dominant decision maker of Indian houses towards purchasing.

\section{SOCIAL IMPACT}

Much social impact is behind here on purchasing any electronic products by the house wife. In that few would be inevitable: -

\section{i. Neighbours' Products}

The Neighbours in apartments or colonies are mingling with each other very close like one family. They even share every minute thing with the neighbours according to the relationship. In such a condition, the electronic products are also made an example to purchase the same or alike one. This not only brings happiness but also the competent in the lifestyle in the particular put-up.

\section{ii. Visual Media}

In Coimbatore, the local TV channels are advertising many products and services from the local made to the international brand. The multi dimensional view of these electronics products enhances the idea of a wife to purchase it. The price which they mentioned in the does not have much negative impact. Because the manufacturers very well identified that the cost of the product could match with the purchasing capacity of the consumer.

\section{iii. Store Atmosphere}

Show rooms like LG and Sony are all showing a rich ambience inside which the consumers especially the homemakers would prefer a better place to purchase the electronic products. The expandable view of the store has given an opportunity for the consumers to relax purchase of commodities. In addition to this, it is fashion that some electronic showrooms are opening cafes and lounges inside the showroom to boost their brands and warm up to future customers.

\section{iv. Exhibition}

The women of the house who is attracted by seeing all the brands of electronic goods at one place. Of course in the city there are more than 50 best showrooms can come to one place to display their products for the perusal of the customers. The exhibition is the one place which is viable to fulfill the meetings in between the electronic sellers and buyers [6]. From mixi to wet grinders, from head phone to wireless speakers, every things is available at the discounted prices. This attribute pull the women of the house towards the exhibition. The choices are more, very fabulous varieties, and expected features in the products makes very happy to 
purchase it.

\section{v. $\quad$ Online Purchasing}

If the consumers would have a clear idea about the product that would have been purchased in online is the best convenient view. A satisfied customer is a loyal customer. If the first online purchasing of the consumer would brought a satisfaction then that would bring the continuous purchasing as well as the loyalty towards that product and website. Behind this it is an innovative idea, because it minimizes the travelling time from home to the shop, minimizing expenditures reduce the involvement of the sales person and an easy pay. It is a $24 x 7$ purchasing mode [6].

\section{A. Objectives}

a. To study about the impact factors of electronic goods by the consumers related with home makers.

b. To examine about the relationship between the demographic issues with the acquiring strategies.

c. To study about the varieties and the preference of consumers towards the varieties.

d. To identify with the usage of electronics goods by the women of the house.

e. To recognize about the opinion of consumers related with price, quality, package and quantity.

\section{B. Limitations}

a. Only a short span of time period have been used to collect the data.

b. The researcher is actually explained about the research and its objectives and face many complicated issues to receive the data from the home makers.

c. The researcher has used the apartment and well settled areas in coimbatore city level.

C. Hypothesis

a. The Experience of the women in the wife accepting factor may have relationship with the purchasing of the electronic goods.

b. There is significant relationship between the experience and the time of purchase of the electronic commodities.

c. There is significant relationship between price of the product and expected feature of the electronic goods.

D. Tools Used
a. Frequencies analysis
b. Ratio Statistics and investigation
c. One way ANOVA
d. Weighted estimation (Weight Least Square Analysis)
e. Two step Cluster Analysis
f. Factor Analysis
g. X-Bar, R, chart for cases of units

\section{LITERATURE REVIEW}

P. Konje [10], This research is actually exists in Zimbabwe in where the imports are more than $90 \%$ of the household electrical goods. The manufacturers contribute less than $10 \%$ of the household electrical goods which is actually required for the people. The electronic appliances like Refrigerators and induction stove are basically imported from South Africa and from Dubai. Manufacturers of these products In Zimbabwe import about $80 \%$ of their inputs. Only $20 \%$ of raw materials are available in this country and contribution of this manufacturers to the GDP of the country is very low.

Apoorva Gupta [11], India has significantly improved the competition climate in its manufacturing sector since 1991 with a string of transform in both domestic and international business policies and plans. The effect of these policies is actually impact with the household commodities which is used by the consumers. In these sectors, due to easy of entry of firms in the market, competition has increased, while in some other sectors, due to the survival of fittest strategies, competition has reduced. Indian Electronic and IT sector is one major segment where the effect of the liberalization and in turn the effect of competition issues have been seen in its totality. This sector in itself is so vast that covering each and every issue will be cumbersome. Thus, we focus on Television industry among the immense pool of gadgets.

Eduardo Torres-Moraga, Arturo Z. Vásquez-Parraga, Jorge Zamora-González [12], Studies on customer satisfaction and loyalty have focused on brand rather than product. It is not that brand is not important, but the process of loving a brand starts with a product. Customers appreciate products by themselves, independent of the brand, as shown in their pursuit of satisfaction and development of loyalty. Such appreciation seems to be prominent regarding innovative products when compared to traditional products. This research is actually had endeavour to investigate this issue and provide a product-brand typology.

Results show that the relationship in between the satisfaction and loyalty is significantly present when evaluating products alone albeit a weaker presence than when evaluating brand alone. Such unequal presence is corroborated in both traditional (bottled wine) and innovative (electronic) products even though it is much stronger in innovative products. The relationship satisfaction-loyalty is also present when evaluating product and brand combined, indicating that there is an intermediate position between product and brand. In contrast, the literature treats brand and product-brand as being in the same category thereby diminishing the importance of a useful difference between brand and productbrand.

James R. Otto, William Wagner [13], A significant advantage to third party administration of consumer ratings, at least from the consumer perspective, is the credibility of the rating information. Self reporting, or advertising, of customer ratings by a vendor might be more suspect than an independent entity providing the same information. An additional advantage to an independent entity managing vendor rating is in the area of standardization of data. An intermediary can collect the same type of consumer feedback, using the same methodology, across many vendors. This provides common data that can be compared across different vendors.

This paper analyzed online customer ratings of electronic 
goods e-tailers to develop neural network and multiple regression models that predict, with good accuracy, customer Overall Satisfaction ratings based on user ratings of Customer Service, Delivery, Ease of Purchase, Price, and Shipping Options. These models can be used to support management decisions on how to apportion investments across these different factors. An important area for future research would be to evaluate the stability of the models (how much they may change) over time.

In [14], Working with a platform like Pay Loadz makes it even easier to sell downloads and receive payments through PayPal. Digital goods are easily sold online, but how do one accept payments and deliver the media? PayPal allows for a low-cost and easy way to collect payments from your customers, but does not have any delivery mechanism or secure means of protecting your items from unauthorized downloads.

That is where Pay Loadz comes in. Our system interfaces with Pay Pal to secure your digital good and only to provide access to those paying customers. Pay Pal offers digital good sales protection for both the buyer and the seller which helps reduce the risk of fraud and charge backs. The Pay Loadz system ensures delivery of your product to your customers which also prevents charge backs while minimizing fraud.

\section{EXPERIENCE OF THE CUSTOMER}

Experiences of the customer have been even given more importance by the sellers or manufacturers. Because, the more experience of a customer will cause for more expectation. On the other side these expectations must be fulfill by the manufacturer by their valuable production [6]. In the purchasing of the consumer electronic goods, this experience will help a person to buy a good which is better in quality and durability.

- $\mathrm{H}_{0}$ : The Experience of the women in the wife accepting factor doesn't have any relationship with the purchasing of the electronic goods.

- $\mathrm{H}_{1}$ : The Experience of the women in the wife accepting factor may have relationship with the purchasing of the electronic goods.

\section{Experience}

Table of Frequencies

Table 1: Experience of the Customer

\begin{tabular}{|c|c|c|c|c|c|}
\hline Years & & Frequency & Percent & Valid Percent & $\begin{array}{c}\text { Cumulative } \\
\text { Percent }\end{array}$ \\
\hline \multirow{7}{*}{ Valid } & 1 & 6 & 5.2 & 6.0 & 6.0 \\
\cline { 2 - 6 } & 2 & 10 & 8.6 & 10.0 & 16.0 \\
\cline { 2 - 6 } & 3 & 32 & 27.6 & 32.0 & 48.0 \\
\cline { 2 - 6 } & 4 & 36 & 31.0 & 36.0 & 84.0 \\
\cline { 2 - 6 } & $\begin{array}{c}5 \text { and } \\
\text { above }\end{array}$ & 16 & 13.8 & 16.0 & 100.0 \\
\cline { 2 - 6 } & Total & 100 & 86.2 & 100.0 & \\
\hline Missing & System & 16 & 13.8 & & \\
\hline \multicolumn{2}{|c|}{ Total } & 116 & 100.0 & & \\
\hline
\end{tabular}

\section{- $\quad$ Inference}

From the above frequency table the numbers of years of experience of the women under the wife accepting factors have been given. In the nearly 84 percentage of the customers (Wife) who are all having more than four years of experience. They are all purchasing or referring electronic goods to their neighbours is because of their experience. Even one year of experience with these electronic goods may give a lot of exposure on operating that [4]. So hence here the alternative hypothesis is accepted because the null hypothesis is getting rejected. More strategies can be framed by the consumers on purchasing of the electronic goods is only by the way of experience.

\section{Time of Purchase Related With Experience}

It is an expression based analysis. The researcher absolutely wants to know about the significant relation in between the time of purchase and the experience. Based on these conditions a case processing summary has been here to analyse the relationship. The purchase experience could have been caught on the time of the product to be purchased. May be it is a traditional sense, but really helpful for the wife of a family for the right product at the right time [5].

- $\mathrm{H}_{0}$ : There is no significant relationship between the Experience and time of purchase of electronic commodities.

- $\mathrm{H}_{1}$ : There is significant relationship between the experience and the time of purchase of the electronic commodities.

\section{Ratio Statistics}

\section{Case Processing Summary}

Table 2: Relationship between Time of Purchase and Experience

\begin{tabular}{|c|c|c|c|}
\hline & & Count & Percent \\
\hline \multirow{4}{*}{$\begin{array}{c}\text { Time of } \\
\text { Purchase }\end{array}$} & During Offer & 36 & $36.0 \%$ \\
\cline { 2 - 4 } & Festival Season & 38 & $38.0 \%$ \\
\cline { 2 - 4 } & $\begin{array}{c}\text { Exhibhange mela } \\
\text { season }\end{array}$ & 16 & $16.0 \%$ \\
\cline { 2 - 4 } & $\begin{array}{c}\text { According to the } \\
\text { available cash }\end{array}$ & 4 & $6.0 \%$ \\
\hline \multicolumn{2}{|c|}{ Overall } & 100 & $100.0 \%$ \\
\hline \multicolumn{2}{|c|}{ Excluded } & 16 & \\
\hline Total & 116 & \\
\hline \multicolumn{2}{|c|}{}
\end{tabular}

- Inference

During offer and festival season the sellers might reduce the price of electronic goods. In that time there could be more varieties also [10]. The wife of the family is not only looking for the better product but also purchase the same one in an economic condition. In such a case the offer period and festival season are the major expected time for the purchasing the electronic commodity [7]. The alternative hypothesis here is accepted. For example the price of Air condition in the 
summer season would be very high, at the same time in the winter season it would be low. So the later time, is the preference of the lady to avail the good.

Table 3: Consumers Income and Experience on Purchasing

Ratio Statistics for Income / Experience

\begin{tabular}{|c|c|c|c|}
\hline Group & $\begin{array}{c}\text { Price } \\
\text { Related } \\
\text { Differential }\end{array}$ & $\begin{array}{c}\text { Coefficient of } \\
\text { Dispersion }\end{array}$ & $\begin{array}{c}\text { Coefficient of } \\
\text { Variation }\end{array}$ \\
\cline { 4 - 4 } & $\begin{array}{c}\text { Median } \\
\text { Centered }\end{array}$ \\
\hline During Offer & 1.025 & .456 & $62.2 \%$ \\
\hline Festival Season & 1.350 & .811 & $138.3 \%$ \\
\hline Exchange mela & 1.329 & .633 & $115.4 \%$ \\
\hline $\begin{array}{c}\text { Exhibition Price } \\
\text { season }\end{array}$ & 1.039 & .200 & $32.2 \%$ \\
\hline $\begin{array}{c}\text { According to the } \\
\text { available cash }\end{array}$ & 1.000 & .200 & $23.1 \%$ \\
\hline Overall & 1.231 & .626 & $114.9 \%$ \\
\hline
\end{tabular}

From the above table, it is understood by the researcher that the income of the family is inevitable for the survey on day to day basis. The co-efficient of the variable says that the exchange mela of electronic goods, utilized by the consumers very well. Because city like Coimbatore is having the pool of electronic goods. One consumer gets the products from very low price to very high price.

The people of this city want to update the electronic good according to fashion and convenience. But, the outdated products cannot be retained. So they go for exchange it. For all the goods exchange is not possible. For example: - Iron box, Electric cooker, Laptop with outdated version of features [7]. But for some commodities like mobile phone, there would be 365 days exchange. But, for many people the income is very low, so they save the money for the future purchasing and wait for the best model.

\section{Relationship Between Price and Feature}

The women of the family are more price sensitive. Because she does have more financial commitments. Beyond this, the nick name of the wife in the home has been called as finance minister for the home [9]. Because, she puts the budget, maintain that, retain some amount for savings and investment and more. The researcher wants to know about the above mentioned statements by using one way ANOVA.

- $\mathrm{H}_{0}$ : There is no significant relationship between price of the product and expected feature of the electronic goods.

- $\mathrm{H}_{1}$ : There is significant relationship between price of the product and expected feature of the electronic goods.

\section{- Inference}

The significance is less than 0.05 . Hence, the null hypothesis is accepted. From the below table, it is understood that the features of the products will be given more importance. For example, a fully automated washing machine contains more and more feature which gives the convenience to the wife in her busy schedule. But the price of the fully automated washing machine is more [3] [4]. In this case, the customer is expecting the comfortable of the product not the price. On the other hand, based on the customer interest the retailers are reducing the price in the name of offer.

Table 4: Relationship between Price and Feature of Products

\begin{tabular}{|c|c|c|c|c|c|}
\hline \multicolumn{7}{|c|}{ One way ANOVA } \\
$\begin{array}{c}\text { Expected } \\
\text { Features }\end{array}$ & $\begin{array}{c}\text { Sum of } \\
\text { Squares }\end{array}$ & df & $\begin{array}{c}\text { Mean } \\
\text { Square }\end{array}$ & F & Sig. \\
\hline $\begin{array}{c}\text { Between } \\
\text { Groups }\end{array}$ & 141.917 & 3 & 47.306 & 6.616 & .000 \\
\hline $\begin{array}{c}\text { Within } \\
\text { Groups }\end{array}$ & 686.443 & 96 & 7.150 & & \\
\hline Total & 828.360 & 99 & & & \\
\hline
\end{tabular}

A. Design, Brand, Quality

It is not so easy that which brand should be highlighted to the customers for their selection. But the idea of the customer especially the housewife does not only focus to the brand but also to the design and quality. Quality is the passion and this spirit has lent them a cutting edge to predominate in the segment across the world [8]. This idea is actually brought the sense to the researcher to analyse how a design, brand and quality. It will help to identify how the electronic goods manufacturers actually designs a new product to the customers

Table 5: Weighted Least Squares Analysis (Price and Features)

\begin{tabular}{|c|c|c|}
\hline \multicolumn{3}{|c|}{ Log-Likelihood Values } \\
\hline \multirow{7}{*}{} & -2 & -129.425 \\
\cline { 2 - 3 } & -1.5 & -126.761 \\
\cline { 2 - 3 } & -1 & -125.316 \\
\cline { 2 - 3 } & -0.5 & $-1.251 \mathrm{E} 2$ \\
\cline { 2 - 3 } & 0 & -126.276 \\
\cline { 2 - 3 } & 0.5 & -128.813 \\
\cline { 2 - 3 } & 1 & -132.820 \\
\cline { 2 - 3 } & 1.5 & -138.365 \\
\cline { 2 - 3 } & 2 & -145.502 \\
\hline
\end{tabular}

\section{- Inference}

From the above the above table the log likelihood values have analyzed the power of choices of consumers (wife of the family) towards the design of the product. The design as per their expectations and convenience will give more suitable chance to purchase. On the other hand the ladies in the home will always think about the spacious positions of products and added value of decoration. In this condition they are giving importance for the design and the shape would also be included with that [6]. Personal computer with printer for example, they manage with a compact computer table. Beyond this, the Laptops are the better choice and they replace the desktop for a spacious perception. 
Table 6: Product Design and Brand

\begin{tabular}{|c|c|c|}
\hline \multicolumn{3}{|c|}{ Model Description } \\
\hline \multicolumn{2}{|c|}{ Dependent Variable } & Design \\
\hline Independent Variables & 1 & BrandImage \\
\hline \multirow{2}{*}{ Weight } & Source & Quality \\
\cline { 2 - 3 } & Power Value & -.500 \\
\hline
\end{tabular}

New models are always welcomed by the ladies by its attraction, price and design. The updated version in the electronic goods is always facilitating the consumers on their process of work in day to day life styles [5]. And definitely, the model gives convenience in usage of the electronic good. Kitchen laptop (induction stove) for example, it not only make the consumers pretty but also replenish the enjoyment in the kitchen.

Table 7: Multiple Regression for Design and Brand

\begin{tabular}{|c|c|}
\hline Multiple R & .129 \\
\hline R Square & .017 \\
\hline Adjusted R Square & .007 \\
\hline Std. Error of the Estimate & 1.044 \\
\hline Log-likelihood Function Value & -125.134 \\
\hline
\end{tabular}

Table 8: Brand Equity with design and Model

ANOVA

\begin{tabular}{|c|c|c|c|c|c|}
\hline & $\begin{array}{c}\text { Sum of } \\
\text { Squares }\end{array}$ & df & $\begin{array}{c}\text { Mean } \\
\text { Square }\end{array}$ & F & Sig. \\
\hline Regression & 1.811 & 1 & 1.811 & 1.661 & .201 \\
\hline Residual & 106.878 & 98 & 1.091 & & \\
\hline Total & 108.689 & 99 & & & \\
\hline
\end{tabular}

\section{- Inference}

The $\mathrm{R}$ value and the Regression shows that the average number of consumers who prefer the electronic goods by having the analyze of the design, model, brand and quality. Because, brand is always enrich the product for its better sale and consumption. Brand gives the proud for the consumer for the loving the commodities [7]. Without the brand, nothing to be notified as gallant. This is more prevalent that the image of the house would be more plenteous.

- $\mathrm{H}_{0}$ : There is no significant relationship between the quality with the design and brand.

- $\mathrm{H}_{1:}$ There is significant relationship between the quality with the design and brand.
Table 9: Brand Image of Consumer Perception

\begin{tabular}{|c|c|c|c|c|c|c|}
\multicolumn{7}{|c|}{ Coefficients } \\
& \multicolumn{2}{|c|}{$\begin{array}{c}\text { Unstandardized } \\
\text { Coefficients }\end{array}$} & \multicolumn{2}{|c|}{$\begin{array}{c}\text { Standardized } \\
\text { Coefficients }\end{array}$} & \multirow{2}{*}{ t } & Sig. \\
\hline & B & $\begin{array}{c}\text { Std. } \\
\text { Error }\end{array}$ & Beta & $\begin{array}{c}\text { Std. } \\
\text { Error }\end{array}$ & & \\
\hline (Constant) & 2.326 & .224 & & & 10.365 & .000 \\
\hline BrandImage & -.113 & .087 & -.129 & .100 & -1.289 & .201 \\
\hline
\end{tabular}

\section{- Inference}

From the above table, the significance of the brand image in more than .05 . Hence null hypothesis is rejected, Here the alternative hypothesis becomes worked out. Because, the consumers will always compare the design, quality and brand frequently especially for the electronic products. In this case, the retailers' or salesman opinion will play a major role. Because, they will suggest suitable things to the customers according to the customers' choices or preferences. The best brand image is also required for the retailers or sellers and even to manufacturers, for better sales.

\section{B. Guarantee, Warrantee, Situation of Claim}

Many Consumers are having awareness about guarantee and warrantee especially to the electronic goods [9]. Because, any damage occurs, this category would help to renew the spare parts and the entire product.

Table 10: Preference towards Guarantee, warrantee and Claim

\section{Cluster Distribution}

\begin{tabular}{|c|c|c|c|c|} 
& & $\mathrm{N}$ & $\begin{array}{c}\% \text { of } \\
\text { Combined }\end{array}$ & $\begin{array}{c}\% \text { of } \\
\text { Total }\end{array}$ \\
\hline \multirow{3}{*}{ Cluster } & 1 & 32 & $32.0 \%$ & $27.6 \%$ \\
\cline { 2 - 5 } & 2 & 18 & $18.0 \%$ & $15.5 \%$ \\
\cline { 2 - 5 } & 3 & 24 & $24.0 \%$ & $20.7 \%$ \\
\cline { 2 - 5 } & 4 & 26 & $26.0 \%$ & $22.4 \%$ \\
\cline { 2 - 5 } & Combined & 100 & $100.0 \%$ & $86.2 \%$ \\
\hline \multicolumn{2}{|c|}{ Excluded Cases } & 16 & & $13.8 \%$ \\
\hline \multicolumn{2}{|c|}{ Total } & 116 & & $100.0 \%$ \\
\hline \multicolumn{2}{|c|}{} \\
\hline \multicolumn{2}{|c|}{} \\
\hline
\end{tabular}

Table 11: Cluster Analysis for Warrantee Related with the Situation

Centroids

\begin{tabular}{|c|c|c|c|}
\hline \multirow{4}{*}{} & & \multicolumn{2}{|c|}{ SituationWarrantee } \\
\hline & & Mean & $\begin{array}{c}\text { Std. } \\
\text { Deviation }\end{array}$ \\
\hline \multirow{4}{*}{ Cluster } & 1 & 3.1875 & 1.20315 \\
\cline { 2 - 4 } & 2 & 2.7778 & 1.26284 \\
\cline { 2 - 4 } & 3 & 3.2500 & 1.56733 \\
\cline { 2 - 4 } & 4 & 4.2308 & 1.06987 \\
\cline { 2 - 4 } & Combined & 3.4000 & 1.36330 \\
\hline
\end{tabular}

- Inference

People may impressed about the presentation of the 
product but also they impressed with the services that bounded with the product. In this aspect the researches have analyzed the specific service which is commonly known as Guarantee, Warrantee of the products. Because it is a promise what the manufacturers are giving to the customers.

Washing machine for example, the sellers have given three years to five years warrantee where the consumers psychologically impacted with the thoughts of customers. In the producers side they have to be lead their position in competition. In such situation a product like Nokia has given a minimum of one year warrantee to all its mobile, and in addition they have extended the free servicing charge for their mobile phones, by introducing some additional charges. It is a tenet of marketing [2].

Table 12: Customer Opinion towards Guarantee and Warrantee

GuranteeWarantee

\begin{tabular}{|c|c|c|c|c|c|c|c|c|c|c|c|}
\hline & & \multicolumn{2}{|c|}{ Highly Satisfied } & \multicolumn{2}{|c|}{ Satisfied } & \multicolumn{2}{|c|}{$\begin{array}{c}\text { Neither Satisfied Nor } \\
\text { Dissatisfied }\end{array}$} & \multicolumn{2}{|c|}{ Dissatisfied } & \multicolumn{2}{|c|}{ Highly Dissatisfied } \\
\hline & & Frequency & Percent & Frequency & Percent & Frequency & Percent & Frequency & Percent & Frequency & Percent \\
\hline \multirow{5}{*}{ Cluster } & 1 & 0 & $.0 \%$ & 32 & $100.0 \%$ & 0 & $.0 \%$ & 0 & $.0 \%$ & 0 & $.0 \%$ \\
\hline & 2 & 18 & $100.0 \%$ & 0 & $.0 \%$ & 0 & $.0 \%$ & 0 & $.0 \%$ & 0 & $.0 \%$ \\
\hline & 3 & 0 & $.0 \%$ & 0 & $.0 \%$ & 0 & $.0 \%$ & 18 & $100.0 \%$ & 6 & $100.0 \%$ \\
\hline & 4 & 0 & $.0 \%$ & 0 & $.0 \%$ & 26 & $100.0 \%$ & 0 & $.0 \%$ & 0 & $.0 \%$ \\
\hline & Combined & 18 & $100.0 \%$ & 32 & $100.0 \%$ & 26 & $100.0 \%$ & 18 & $100.0 \%$ & 6 & $100.0 \%$ \\
\hline
\end{tabular}

\section{- Inference}

According to the recommendations of many researches, people are keen about products with warrantee and recently $50 \%$ market share is what Finnish mobile handset maker Nokia said it is targeting in India on the back of innovative products, services and content within 2012. The company is banking on its newly unveiled mid-end phones from the 'Asha' series priced between Rs. 4,100 and Rs. 8,000 and other smart phones, including the new two Lumia models with Windows OS tagged at about Rs. 29,000 and Rs.19,000 respectively.

\section{Technical Details, Brand Image, Comfortable}

The wife of the family actually knows the best. Today marketers and producers cannot compel customers to do things that they do not want to-do. Customers must be informed with the technical details about the electronic item which they are purchasing. Because the later version has to be operated by the ladies in the home very confidently [4] [7]. The surefooted approach increase the freedom and comfortable in operating the highly defined items. In this view the researcher had an idea to analyse the customers' knowledge in technical details and how the brand image would bring the solid sense to the customers.

Table 13: Comfortable on Commodities

\section{Communalities}

\begin{tabular}{|c|c|c|}
\hline & Initial & Extraction \\
\hline TechnicalDetails & 1.000 & .569 \\
\hline BrandImage & 1.000 & .388 \\
\hline Comfortable & 1.000 & .611 \\
\hline
\end{tabular}

\section{EXTRACTION METHOD: PRINCIPAL COMPONENT} ANALYSIS.

A. Only Cases for which Recent Modification = Highly Agree are used in the Analysis Phase.

\section{- Inference}

We understood from the above table the extraction in the factor analysis for technical details and the comfortable that the wife is made with the value drive in her day to day life. If the sellers have an idea about the customer centric approach then it would be a great success, because consumers (the wife of the home) appraised for the better passion that they emotionalized with [8] [6] [4]. However, the brand image is caused by the brand awareness and this would encourage and pull the customers towards purchasing of commodities.

Table 14: Brand Awareness

Total Variance Explained

\begin{tabular}{|c|c|c|c|c|c|c|}
\hline \multirow{2}{*}{$\begin{array}{c}\text { Compo } \\
\text { nent }\end{array}$} & \multicolumn{3}{|c|}{ Initial Eigen values } & \multicolumn{3}{|c|}{$\begin{array}{c}\text { Extraction Sums of Squared } \\
\text { Loadings }\end{array}$} \\
\cline { 2 - 7 } & Total & $\begin{array}{c}\% \text { of } \\
\text { Variance }\end{array}$ & $\begin{array}{c}\text { Cumulative } \\
\%\end{array}$ & Total & $\begin{array}{c}\text { \% of } \\
\text { Variance }\end{array}$ & $\begin{array}{c}\text { Cumulative } \\
\%\end{array}$ \\
\hline 1 & $\begin{array}{c}1.56 \\
8\end{array}$ & 52.282 & 52.282 & 1.568 & 52.282 & 52.282 \\
\hline 2 & .817 & 27.232 & 79.514 & & & \\
\hline 3 & .615 & 20.486 & 100.000 & & & \\
\hline
\end{tabular}

Component Matrix a,b 
Table 15: Brand Image and Comfortable

\begin{tabular}{|c|c|}
\hline & Component \\
\hline & 1 \\
\hline TechnicalDetails & -.754 \\
\hline BrandImage & .623 \\
\hline Comfortable & .782 \\
\hline
\end{tabular}

The consumer develops a set of brand belief about where each brand stands on each attribute. The set of belief about a brand make up the brand image. The consumer's brand image will vary with his or her experiences as filtered by the effects of selective perception. Brands vary in the amount of power and value they have in the market place. At one extreme are brands that are not known by more buyers. Then there are brands for which buyers have a fairly high degree of brand awareness. Beyond this are brands with a high degree of brand acceptability.

\section{- Inference}

The comfortable for an electronic good is very essential for ladies who consume it frequently. For example, a fully automated washing machine would do all the functions from the on button to the completion of the work. So in the mid time the wife of the family doesn't essential to concentrate on washing works. She would attend other works to finish it as much as speedy.

If the wife plays role as a home maker a full automated electronic good will give much comfortable, and for a working lady it would helpful and assist to complete the morning works according to the expectation. There is no denial of the fact that the future belongs to the electronics goods and the eyes of the Wife of the family are now towards that. Beyond this, the brand image would fulfill the categorization of the electronic product and it aspirant and lifestyle. Because, today the trend is having dramatic change. However, the consumers have their own choices in these electronic goods. For example, mobile phones.

\section{Planning To Purchase}

A life style is a person's pattern of living in the world as expressed in activities, interests, and opinions. Marketers search for relationships between their products and life style groups. In the case of mobile phone, model, price and offers are all the key identification of consumer that they would go for better choices. However, cell phone market is a highly competitive market [2] [3]. Technology and product features play a dominant role in case of Indian cell phone market. The consumers always like the technologically superior products. So it is very essential to understand the perception and preference of customers regarding the cell phones in Indian market. Particularly in the case of brand new cell phone manufacturer.

\section{- Inference}

The world has changed and today all the persons need some technologically advanced product in their hands. Especially the wife of the family requires those product, not only to enrich the life but also for a provision of material help in their busy schedules. By considering this from the above $\mathrm{X}$ bar chart the consumers are considering the quality, latest technology and model in very high level. Price may not be a key concentrate variable to them. Because, they would consider durability as a factor, more than that.

\section{FINDINGS}

1. The design as per their expectations and convenience will give more suitable chance to purchase.

2. On the other hand the ladies in the home will always think about the spacious positions of products and added value of decoration.

3. New models are always welcomed by the ladies by its attraction, price and design. The updated versions in the electronic goods are always facilitate the consumers on their process of work in day to day life styles.

4. Brand gives the proud for the consumer for the loving the commodities. Without the brand, nothing to be notified as gallant. This is more prevalent that the image of the house would be more plenteous.

5. Because, the consumers will always compare the design, quality and brand frequently especially for the electronic products.

6. People may impress about the presentation of the product but also they impressed with the services that bounded with the product.

7. In this aspect the researches have analyzed the specific service which is commonly known as Guarantee, Warrantee of the products. Because it is a promise what the manufacturers are giving to the customers.

8. If the sellers have an idea about the customer centric approach then it would be a great success, because consumers (the wife of the home) appraised for the better passion that they emotionalized with.

9. However, the brand image is caused by the brand awareness and this would encourage and pull the customers towards purchasing of commodities.

10. The consumer develops a set of brand belief about where each brand stands on each attribute. If the wife plays role as a home maker a full automated electronic good will give much comfortable, and for a working lady it would helpful and assist to complete the morning works according to the expectation.

\section{SUGGESTIONS AND CONCLUSION}

1. Companies or producers have to do many research to find out the cognition of ladies who dominates on purchasing.

2. Price is still a sensitive issue to them. So the producers must justify an electronic product on its price.

3. Now a day products are customized to digital. In this occasion, the idea must be build for better brand image and the quality is also must be checked frequently for a better customer satisfaction.

4. A regular communication and announcement of 
product to the customers by using advance media techniques is inevitable.

5. In Coimbatore city, the customers are merely think about the exchange of old goods to the new goods. For example, Big Bazaar in this city is having a name for good exchange value.

6. Festival season offers are mostly attracted by the customers. If there is permanent offer for electronic goods in most times, then it would lose its credibility.

7. One "mantra" is needed to the producers of electronic goods very much. They are giving changes to the consumers (wife of the family whom using the electronic goods frequently) from the hectic life style to a happy livings.

\section{REFERENCES}

[1] Electronic Marketing: Advantages and Disadvantages, Najib Fatayerji, ISBN1581122217, 9781581122213, 2004.

[2] Strategic Internet marketing, Tom Vassos, Que, the University of Virginia, ISBN0789708272, 9780789708274, 1996.

[3] Conceptualizing Marketing Communication in the New Marketing Paradigm: A Postmodern Perspective, Wilson F. Ozuem, UniversalPublishers, ISBN1581122470, 9781581122473, 2004

[4] Successful marketing communications: a practical guide to planning and implementation, Cathy Ace, Chartered Institute of Marketing, Butterworth-Heinemann, , ISBN0750650273, 9780750650274, 2001

[5] Marketing communications management: concepts and theories, cases and practices, Paul Copley, Butterworth-Heinemann, ISBN0750652942, 9780750652940, 2004

[6] The face of Marketing; Pitch, Vol. 9, No. 2, November 2011

[7] Point of Purchase; Vol. 7, No. 4, November 2011.

[8] Retailer, Vol. 6, No. 8, November 2011

[9] Storai, Vol. 2, No. 6, September-October 2011

[10] P. Konje, "Household Electrical Goods", www.zimtrade.co.zw/ 2011

[11] Apoorva Gupta, "Competition Issues in Electronic Goods Sector: Television Industry”, 2010

[12] Eduardo Torres-Moraga, Arturo Z. Vásquez-Parraga, Jorge ZamoraGonzález, "Customer satisfaction and loyalty: start with the product, culminate with the brand", Journal of Consumer Marketing, Vol. 25 No. 5, Pp. 302 - 313. 2008

[13] James R. Otto, William Wagner, "Analysis of Online Customer Reviews”, Journal of Business \& Economics Research, Vol. 2, No. 10, 2004

[14] http://www.payloadz.com/info-paypal-downloads.asp

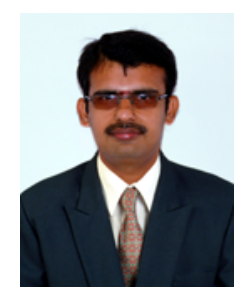

Dr.S. Aravinth is working as an Associate Professor in School of Management, Sri Krishna College of Technology, Coimbatore, Tamil Nadu, India. He is having 12 years of Experience in Education and 8 Years of Research entity. He has presented many papers in national and international conferences. And he also published research and conceptual article in reputed international journals. He is also involved in many consultancy works for leading firms in Coimbatore. He does have experience in developing portfolio, infrastructures and Academic Schedules for Deemed Universities, Business Schools in Engineering institutions and Stand Alone Business School Institutions.

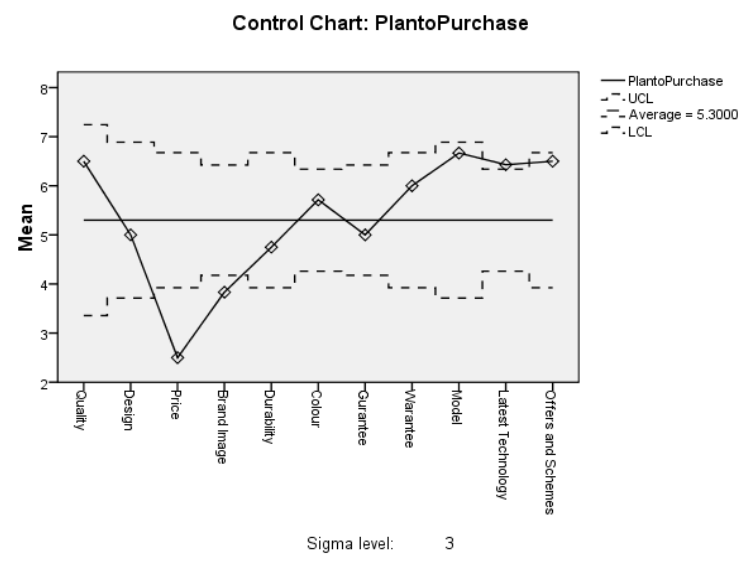

Figure 1: Planning to Purchase

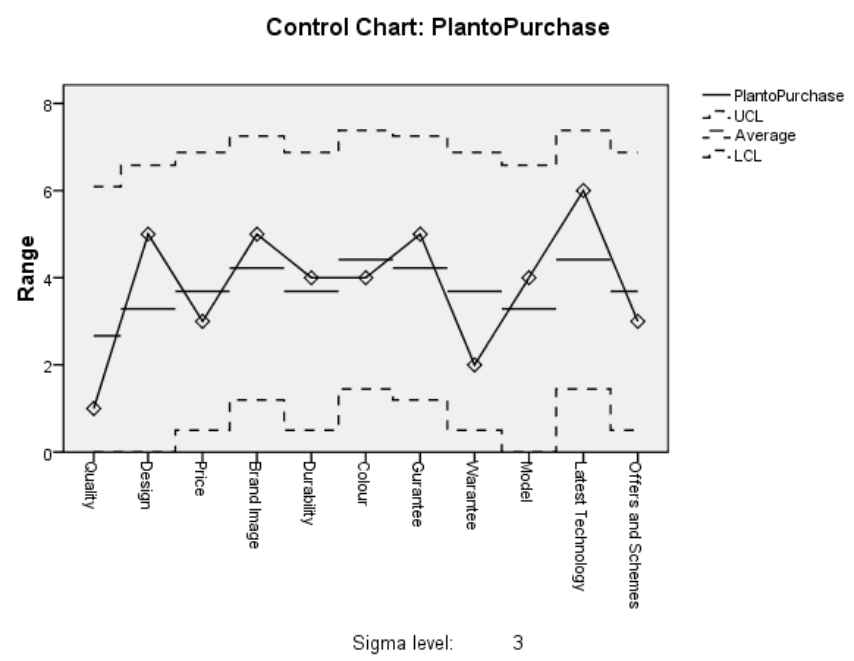

Figure 2: Planning to Purchase 